of Loch Assynt and is a typical sample of west Sutherland countryside, ranging in altitude from about $23 \mathrm{v} \mathrm{ft}$. near Inchnadamph to $1,680 \mathrm{ft}$. on the summit of Beinn nan Cnaimhseag. Loch Mhaolachcoire is included within its boundaries. The reserve lies in a tract of great geological and physiographical interest, being at the western front of an area of disturbed Durness limestone of Cambrian age. At $B \in$ inn nan Cnaimhseag is an isolated outcrop of Torridon sandstone resting upon the Durness limestone. Although some of the limestone in the reserve is covered with acid drift and peat, much of it is exposed, and about four hundred acres consists of limestone pavements and scraps. The ground is partially covered by low willow scrub consisting mainly of Salix myrsinites, but also includes S. repens, $S$. aurita and hybrids. Mountain avens (Dryas octopetala) is abundant on the drier limestones, and there is a rich woodland flora of northern character including globe flower (Trollius europaeus) in some parts. The gorge of the Traligill Burn is well known to botanists. The karst type of limestone country with sink-holes, underground streams and limestone caves is also to be found, and the famous Allt nan Uamh bone caves contain Palæolithic cave earths with a fauna of Pleistocene mammals and traces of occupation by early man. The reserve has been established under an agreement with the owner, Mr. R. A. Vestey. The Glen Diomhan nature reserve consists of 24 acres of a steep-sided, post-glacial gorge in north-west Arran, lying between Meall nan Damh $(1,370 \mathrm{ft}$.$) on the west and Ben Bhiorach$ $(1,572 \mathrm{ft}$.) on the east. The area is noteworthy for the occurrence in it of two rare whitebeams (Sorbus arranensis and $S$. pseudofennica), both of which are confined to Arran. They grow intermixed with rowan (S. aucuparia). The trees are mostly confined to a short length of the glen between the $300-\mathrm{ft}$. and 600 -ft. contours and are found on both banks of the stream. The reserve has been established under an agreement with the Dowager Duchess of Montrose.

\section{Three-dimensional and Two-phase Illustrations}

ThE firm of Industrial Photographs, Ltd. (34 Belwell Lane, Four Oaks, Sutton Coldfield), has produced some interesting three-dimensional pictures, called 'Vectographs', in which the solid effect is produced by means of an ingenious application of polarized light. The two component images necessary for a stereoscopic picture are printed in superposition on either side of a transparent support. 'The nature of this support and the printing solution used results in the production of two images in which the original photographic densities are reproduced in varying degrees of optical polarization. The light passed by the first image is polarized at right-angles to that passed by the second. This composite picture is viewed through a small binocular analyser, the lenses of which are two pieces of polarizing material with their cirections of polarization at right angles to one arother; these lenses act as filters and are so arranged that the left and right images are visible only to the appropriate eye, thus producing a clear and striking three-dimensional effect. Three examples of subjects illustrated are the chemical structure of graphite, a shadowed carbon replica of pearlite, and a cone of Chamaecyparis lausoniä. By another application of the process, two different aspects of a subject are similarly superimposed. Each is visible by polarized light in one plane only, and a piece of polarizing filter (or one lens of the binocular viewer) is rotated to show either image or both, or the transition from one to the other. An example of this type of two-phase picture is one in which the two aspects are the human skull and its associated muscles and tissues. The pictures are $4 \frac{1}{4}$ in. $\times 5 \frac{1}{4}$ in. in size and are designed for educational purposes. As an alternative to passing them around the lectureroom, they can be used as slides (though they are rather large ones) and projected on to a metallized screen. Each member of the audience must, of course, have a polarizing viewer.

\section{Antarctica Exhibition at the British Museum (Natural History)}

A sPecras exhibition on Antarctica has been arranged in the Mineral Gallery of the British Museum (Natural History) to mark the International Geo. physical Year, 1957-58 and the 'Trans-Antarctic Expedition. The rock specimens of the Department of Mineralogy, which form the National Collection, include many from Antarctica. Three areas have been selected for exhibition. The first area is South Victoria Land, scene of many British expeditions, culminating in those of Shackleton and Scott. South Victoria Land is now a base for New Zealand and American parties, and the final destination of the Trans-Antarctic Expedition. The second area represented is Queen Maud Land, in the Norwegian section of Antarctica. Part of this territory was explored by the Norwegian-British-Swedish Fxpedition, 1949-52. The third area, part of the Falkland Islands Dependencies, including Graham Land and its offshore islands, is now being surveyed by many British parties. Four historical specimens displayed are : the gizzard stones of an emperor penguin taken on sea ice by Sir James Clark Ross's Expedition (H.M.S. Terror and H.M.S. Erebus) in 1849, which included rocks of continental character, and gave the first scientific evidence for the existence of a southern continent; a boulder of gneiss, a typical continental rock, dredged from the floor of the Southern Ocean by H.M.S. Challenger in 1874, which provided further evidence of a southern continent; rocks c.sllected by Captain Scott's party on their return march from the South Pole in January 1912; and the Adélie Land stony meteorite, which is the only meteorite so far recovered in Antarctica. There are also photographs, paintings and maps illustrating antarctic conditions.

\section{Michael Faraday and Spiritualism}

$I_{N}$ 1853, Michael Faraday conducted an investigation of certain spiritualistic phenomena then causing considerable stir. Using a few simple pieces of apparatus of his own design, he succeeded in establishing the same kinds of controls that characterized his more famous experimental researches and provided a rational explanation for the observed set of pheno. mena that was satisfactory to all. No new and strange forces were uncovered. Instead, Faraday demonstrated conclusively that the performers produced the observed effects by ordinary physical means. What was noteworthy in this inquiry-and the reason Faraday's explanation proved to be satisfactory to both sides-was that he discovered that the performers were deceiving not just others, but themselves as well. Although the performers produced the observed effects, they did so unconsciously.

Faraday investigated two sets of phenomena, the levitation of tables and the turning of tables. In his "Observations on Mental Education", which was 